\title{
MENGHUBUNGKAN CSR RATING, KINERJA PERUSAHAAN DAN NILAI PERUSAHAAN
}

\author{
Imam Nur Hidayat ${ }^{1}$, Ilham Maulana ${ }^{2}$, Nurita Andriani ${ }^{3}$ \\ 1,2,3 Program Studi Magister Manajemen, Universitas Trunojoyo Madura, Bangkalan, Indonesia
}

\section{Ilhammlna01@gmail.com}

Abstract : This research revolves around the effect of company performance, CSR rating on company value by using companies listed on the IDX in 2019, the sample was selected using the purposive sampling method, and got a total of 35 companies as the sample used in the test. The variables used in this study include CSR Rating, Return On Assets and Net Profit Margin as indicators of company performance, Tobin's $Q$ and Price to Book Value as indicators of firm value. SEM-PLS was used as a test tool using WarpPLS 7.0. The variables in this study are transformed formatively into latent variables. The result is that the company's performance has a significant positive effect on firm value, the CSR rating has a positive, weakly significance, and the CSR rating can positively moderate the relationship between company performance and firm value.

Keywords: Firm performance, firm value, CSR rating

\section{PENDAHULUAN}

Faktor apa yang paling mendorong nilai perusahaan? Tentunya adalah kinerja keuangan perusahaan. Perusahaan yang memiliki kinerja keuangan yang baik dan konsisten mendapatkan laba dari tahun-ke tahun pastinya akan memiliki nilai yang lebih tinggi dibandingkan perusahaan yang mengalami kerugian. Di mata investor, kinerja keuangan yang baik menjamin return dari investasinya akan membuahkan hasil. Semakin tinggi kemampuan perusahaan menghasilkan return maka akan semakin tinggi pula nilai perusahaan tersebut.

Kinerja keuangan perusahaan masih menjadi perdebatan di antara para peneliti apakah kinerja perusahaan dapat meningkatkan nilai perusahaan, melihat Nursani (2020; Harningsih et al. (2019); dan Haryanto et al. (2018) yang menemukan hasil kalau kinerja perusahaan akan meningkatkan nilai perusahaan, namun hasil ini kontradiktif dengan Mudjijah et al. (2019); dan Rafid et al. (2017). Padmayanti et al. (2019) justru menemukan jika kinerja keuangan tidak berpengaruh terhadap nilai perusahaan.

Namun dewasa ini, orientasi perusahaan mulai bergeser yang awalnya hanya profit oriented menjadi stakeholder oriented dan untuk mengimplementasikan hal tersebut perusahaan membuat program corporate social responsibility (CSR) (Effendi, 2019; Lindawati \& Puspita, 2015). CSR merupakan program perusahaan yang bertujuan membangun sustainibility perusahaan dengan berinteraksi dengan stakeholder khususnya masyarakat sekitar perusahaan.

Keberadaan CSR kerap dihubungkan dengan meningkatnya nilai perusahaan, banyak peneliti yang berpendapat seperti Masruroh and Makaryanawati (2020); Karina \& Setiadi (2020) mendapatkan temuan bahwa CSR akan meningkatkan nilai perusahaan, bahkan berita mengenai CSR perusahaan dapat meningkatkan nilai perusahaan secara empiris dapat meningkatkan nilai perusahaan (Seok et al. 2020). Namun bagaimana dengan CSR rating?

CSR rating merupakan penilaian yang diberikan oleh agensi khusus yang menilai kinerja CSR yang telah dilakukan perusahaan agensi CSR rating. Dekade belakangan ini CSR atau agensi penilai CSR meningkat pesat dan mulai diketahui banyak pihak. Agensi CSR akan memberikan nilai kepada perusahaan yang dinilai oleh mereka dan bisanya akan di-ranking perusahaan apa saja yang memiliki kinerja CSR terbaik (Scalet \& Kelly, 2010). Penelitian ini ingin membuktikan bahwa kinerja perusahaan memiliki hubungan positif dengan nilai perusahaan dan CSR rating yang diberikan agensi penilai CSR akan memperkuat hubungan keduanya. Upaya ini dilakukan untuk memberi kesadaran kepada berbagai pihak khususnya perusahaan akan pentingnya menilai CSR dijadikan benchmark akan baiknya CSR yang telah dilakukan dan sebagai indikator bagi calon investor dan stake holder lainnya bahwa perusahaan tersebut memiliki daya sustainibility 
yang mumpuni dengan melihat penilaian CSR yang diberikan oleh agensi.

Di negara maju, penggunaan agensi penilai CSR sudah sangat umum dalam mengungkap kualitas CSR suatu perusahaan. Banyak perusahaan yang mengalokasikan sumber daya perusahaan agar dapat melaporkan aktivitas tanggung jawabnya. Berbeda dengan negara dengan pasar berkembang yang lebih berfokus dengan bagaimana perusahaan mendapatkan keuntungan dan kurang tertarik dengan aktivitas pertanggung jawaban perusahaan (Yoon, Lee, \& Byun, 2018).

Indonesia merupakan salah satu negara berkembang di mana aktivitas CSR belum menjadi fokus utama perusahaan. Hanya beberapa saja perusahaan di Indonesia yang menggunakan jasa dari agensi penilai CSR untuk memberikan penilaian. Dalam penelitian ini, penelitian ingin membuktikan secara empiris bahwa tidak hanya kinerja perusahaan dapat meningkatkan nilai perusahaan, namun juga rating yang diberikan oleh agensi rating $C S R$ juga dapat meningkatkan nilai perusahaan.

\section{LANDASAN TEORI}

\section{Kinerja Perusahaan}

Banyak peneliti yang memisah kinerja perusahaan menjadi dua macam yakni kinerja keuangan perusahaan dan nilai pasar perusahaan (Maulana, 2020; Rashid, 2020; Tsai \& Mutuc, 2020), dua macam kinerja yang diukur dalam berbagai penelitian, yaitu kinerja operasi perusahaan dan nilai pasar perusahaan. Kinerja operasi perusahaan diukur dengan melihat kemampuan perusahaan yang tampak pada laporan keuangannya. Untuk mengukur kinerja operasi perusahaan biasanya digunakan rasio profitabilitas. Rasio profitabilitas mengukur kemampuan perusahaan menghasilkan keuntungan yang sifatnya moneter. Peneliti biasanya menghitung keuntungan dengan membandingkannya dengan total aset (ROA), total ekuitas (ROE), margin laba bersih (NPM), margin laba kotor (GPM), modal yang digunakan (ROI), dan bisa dengan membandingkan pendapatan terhadap total saham beredar (EPS). Untuk rasio berdasarkan kinerja harga pasar perusahaan atau nilai perusahaan yang paling umum yakni dengan rasio tobin's q dan price to book value (Brigham \& Houston, 2015).
Mengukur kinerja perusahaan pada dasarnya untuk mengukur tingkat pencapaian yang telah dilakukan oleh perusahaan dalam mencapai tujuan perusahaan yakni mencapai visi dan misi perusahaan yang tertuang dalam perencanaan perusahaan. Pengukuran ini berasal dari kinerja perusahaan di masa lalu yang tercermin di laporan perusahaan maupun di pasar modal. Kinerja perusahaan dinilai pada satuan waktu tertentu, baik kuartal atau laporan tahunan. Memalui analisa kinerja tersebut kita dapat mengevaluasi apakah perusahaan sudah cukupp baik dalam mencapai tujuan perusahaan.

\section{a. Kinerja Keuangan}

Helfert (2001) menjelaskan kinerja keuangan adalah cara perusahaan menilai apakah perusahaan sudah mendapatkan keuntungan dari operasi yang telah dilakukan. Dengan melihat data dari laporan keuangan dan membuat penilaian ekonomis terhadap laporan tersebut. Kinerja keuangan dapat menjadi indikator atas prestasi yang telah dilakukan oleh manajemen dalam satuan periode tertentu. Dalam menilai laporan keuangan ini biasanya baik manajemen, peneliti dan ekonom akan menggunakan rasio tertentu untuk mengetahui sebaik apa kinerja keuangan perusahaan. Rasio tersebut membantu stakeholder perusahaan dalam menilai perusahaan baik secara teknikal, dan fundamental.

\section{b. Nilai Perusahaan}

Titman et al. (2017) mengajukan pertanyaan bagaimana perusahaan akan dinilai oleh pasar? Bukan berdasarkan penilaian akuntansi namun bagaimana pasar saham menilai perusahaan. bagaimana cara menilai kinerja perusahaan di masa lalu untuk menilai nilai perusahaan masa depan? Nilai perusahaan pada dasarnya merupakan nilai perusahaan yang berlaku di pasar. Nilai ini ditujukan untuk mengetahui apakah perusahaan over value atau under value. Semakin besar nilai perusahaan maka semakin tinggi kemakmuran perusahaan. tingginya nilai perusahaan ini berasal dari baiknya keputusan-keputusan perusahaan di masa lalu dalam memanfaatkan seluruh aset perusahaan dalam menghasilkan keuntungan sehingga banyak calon investor yang melirik untuk membeli perusahaan yang menyebabkan nilai perusahaan naik pesat. Titman menjelaskan salah satu untuk menilai perusahaan yakni dengan menggunakan rasio market to book value yang 
mana ini sama dengan price to book value yakni dengan melihat perbandingan harga saham di pasar dengan harga buku saham. Rasio ini menjelaskan jika semakin tinggi maka perusahaan akan dinilai sangat baik karena dapat menguntungkan bagi stakeholder.

Tobins'q salah salah satu cara menilai perusahaan yang melibatkan aset perusahaan, liabilitas, dan market capitalisation dalam rasionya. Diperkenalkan oleh Tobin dan william Brainard dan sangat berdampak dalam makro ekonomi . Dalam rasio tobin nilai 1 artinya nilai perusahaan mencapai equilibrum, jika kurang dari satu berarti perusahaan tersebut dinilai kurang dari seharusnya dan jika lebih dari satu maka perusahaan dinilai lebih dari asset yang dimiliki (M. R. Ali, Mahmud, \& Lima, 2016).

\section{Corporate Social Responsibility}

Meminjam dari Lindgreen \& Swaen (2010) "not only is doing good the right thing to do, but it also leads to doing better" kira-kira seperti itu yang menjadi salah satu ide dasar perkembangan ideologi perusahaan untuk menerapkan CSR. Perusahaan tidak sekedar mengejar keuntungan namun menetapkan posisi perusahaan di dalam masyarakat dan lingkungan. CSR merupakan komitmen pelaku bisnis untuk tetap teguh memegang etika berbisnis dan beroperasi dalam dan juga memberi kontribusi bagi keberlangsungan perusahaan dan stakeholder. Ide dasar ini melihat bahwa bukan hanya profitabilitas saja yang mesti diraih perusahaan melainkan sustainibility atau keberlangsungan perusahaan. Dikatakan sebagai komitmen karena tidak ada aturan hukum bahwa perusahaan wajib melakukan CSR namun lebih kepada kesukarelaan perusahaan untuk menjamin semua pihak yang berhubungan baik langsung atau tidak langsung terpenuhi hak-haknya. Bisa dikatakan CSR merupakan respon perusahaan kepada keinginan dan permintaan stakeholder pada kepedulian perusahaan akan lingkungan, dan sosial (Crisóstomo et al.,2011)

\section{CSR Rating}

CSR rating adalah penilaian yang diberikan oleh perusahaan penilai CSR. Penilaian tersebut biasanya meliputi environment, social, dan governance (ESG) selayaknya agensi akreditasi menilai sesuatu (Saadaoui \& Soobaroyen, 2018). CSR rating dapat menjadi standar pengelolaan
CSR bagi perusahaan yang hendak mengglobalisasi perusahaan (Sandberg et al. 2009). Hal ini melihat perbedaan kultur di seluruh dunia terhadap pandangan bagaimana tanggung jawab sosial diterapkan Sandberg mengajukan adanya standarisasi akan pelaksanaan CSR, dengan melihat hal nilai CSR tersebut semua orang dapat menilai bagaimana perusahaan dijalankan. Dalam hal ini semua orang dimaksudkan kepada stakeholder, yang meliputi konsumen, pegawai, komunitas, aktivis dan publik pada umumnya (Scalet \& Kelly, 2010).

\section{Pengembangan Hipotesis}

\section{Kinerja Keuangan, CSR Rating dan Nilai Perusahaan}

Secara teoritis faktor utama yang mendorong naiknya nilai perusahaan adalah kinerja perusahaan. Kinerja perusahaan yang dianalisa dengan pengukuran tertentu seperti ROA dan NPM dapat menjadi indikator bahwa perusahaan sedang dalam keadaan baik dan mampu mendapatkan keuntungan bagi stakeholder. Keadaan ini akan memicu stakeholder untuk membeli saham perusahaan yang mana ini akan mendongkrak nilai perusahaan. Di kalangan peneliti hal ini dibuktikan dalam penelitian empiris mereka seperti Harningsih et al., (2019); Haryanto et al., (2018) dan Nursani, (2020) yang membuktikan bahwa kinerja perusahaan dapat meningkatkan nilai perusahaan.

Pada dekade belakangan perusahaan mulai memiliki perubahan orientasi, yang pada awalnya hanya memikirkan keuntungan, pada hari ini mulai beralih bahwa orientasi perusahaan seharusnya pada stakeholder perusahaan. Dalam melakukan ini perusahaan akan memerhatikan nilai-nilai etika bisnis perusahaan berupa tanggung jawab perusahaan. Dalam pengimplementasian nilai-nilai yang mengorientasikan kepentingan stakeholder banyak pihak yang menyambut baik. Seiring dengan baiknya aktivitas tanggung jawab yang dilakukan perusahaan maka nilai perusahaan akan meningkat. Argumen ini dibuktikan oleh para peneliti seperti H. Y. Ali et al, (2020), Wong et al., (2020) dan Yoon et al. (2018) yang menunjukkan hubungan positif antara CSR dengan nilai perusahaan.

Kemudian dekade belakangan ini perkembangan agensi CSR yang menilai pelaksanaan tanggung jawab perusahaan mulai 
melakukan standarisasi dan memberikan penilaian dari pelaksanaan tanggung jawab perusahaan. Penelitian mengenai CSR rating yang dinilai dari environment, social dan governance (ESG) sudah ada sebelumnya seperti Atan et al. (2018) namun belum memberikan hasil yang jelas mengenai pengaruh rating tersebut terhadap kinerja perusahaan, sedangkan Yoon et al., (2018) yang meneliti hubungan CSR rating dengan kinerja perusahaan dan nilai perusahaan menemukan bahwa secara positif CSR dapat meningkatkan nilai perusahaan, karena dalam negara dengan pasar berkembang isu mengenai sosial, lingkungan dan tata kelola merupakan isu yang sangat penting dalam meningkatkan nilai perusahaan.

Sebagaimana kinerja keuangan perusahaan dapat meningkatkan nilai perusahaan, keberadaan $C S R$ rating dapat menjadi acuan bagi para investor bahwa perusahaan tersebut memiliki resiko yang rendah untuk investasi, karena perusahaan memiliki keterbukaan dalam menyampaikan kegiatankegiatan tanggung jawab perusahaan yang dapat menjadi jaminan atas keberlangsungan perusahaan.

Dari uraian ini peneliti mengajukan hipotesis penelitian ini :

H1 : Kinerja keuangan perusahaan berpengaruh positif terhadap nilai perusahaan.

H2 : CSR Rating berpengaruh positif terhadap nilai perusahaan.

H3 : CSR Rating dapat memoderasi hubungan kinerja perusahaan dengan nilai perusahaan secara positif.

\section{METODE PENELITIAN}

\section{Jenis penelitian}

Penelitian ini termasuk jenis penelitian kuantitatif empiris karena penelitian ini dilakukan untuk menguji pengaruh variabel independen (return on asset dan return on equity), moderator (CSR rating) terhadap variabel dependen (Price to book value dan Tobin's $Q$ ) pada perusahaan yang terdaftar di BEI dengan periode pengamatan tahun 2019.

\section{Variabel Independen}

Kinerja Keuangan merupakan prestasi kerja yang telah dicapai oleh perusahaan dalam suatu periode tertentu dan tertuang pada laporan keuangan perusahaan yang bersangkutan. Kinerja Keuangan diukur dengan Rasio Profitabilitas.

$$
\text { ROA = Laba bersih setelah pajak/ Total }
$$

Aset

$$
\mathrm{NPM}=\text { Laba bersih setelah pajak / }
$$

Penjualan bersih

\section{Variabel Dependen}

Dalam mengukur nilai perusahaan, penelitian ini menggunakan rasio Price to book value dan Tobin's $Q$. Price to book value diukur dengan membagi harga saham perusahaan terhadap nilai buku saham perusahaan. Tobin's Q diukur dengan rasio nilai kapitalisasi pasar ditambah total liabilitas dibagi total aset.

\section{Variabel Moderator}

Merupakan penilaian yang diberikan oleh agensi rating yang disediakan oleh csrhub.com, peneliti menggunakan overall rating yang dapat diakses oleh peneliti. Penilaian tersebut berasal dari metode penilaian yang dimiliki oleh agensi Csrhub ; sustainibility management tools yang menilai perusahaan dari big data alghorithm untuk menemukan nilai yang sesuai untuk perusahaan Indonesia yang terdaftar di csrhub.

\section{Populasi dan Sampel}

Populasi dalam penelitian ini adalah seluruh perusahaan yang terdaftar di BEI pada periode 2019 dengan menggunakan data yang tersedia di laporan tahunan perusahaan. Sampel yang digunakan dipilih dengan metode purposive sampling (Sugiyono, 2017) yaitu dengan kriteria perusahaan yang mendapat nilai penuh di Csrhub.com, tidak mengalami rugi pada tahun 2019, dan disajikan dengan mata uang rupiah.

\section{Teknik Analisa}

Penelitian ini di analisa dengan statistik deskriptif dan metode PLS dengan bantuan dari aplikasi WarpPLS 7.0. Kinerja keuangan perusahaan yang dinilai dengan akan dimanifestasikan dengan variabel indikator ROA dan NPM perusahaan menjadi variabel laten secara formatif yang disimbolkan dengan nama PROF. Kemudian variabel indikator Tobin's q dan PBV secara formatif menjadi variabel laten nilai perusahaan dan akan disimbolkan dengan VALUE. CSR rating secara formatif akan disimbolkan 
dengan nama RSCR. Data yang telah dikumpulkan akan diuji Goodness fit model, multikolineritas menggunakan nilai VIF (Variance Inflation factor), outer model, inner model dan uji hipotesis menggunakan PLS. Penggunaan model formatif dalam penelitian ini ditujukan karena bentuk data yang digunakan dalam penelitian ini observable data (Solimun et al, 2017)

\section{HASIL \& PEMBAHASAN}

\section{Statistik Deskriptif}

Tabel 1 Statistik deskriptif

\begin{tabular}{|l|c|c|c|c|c|}
\hline \multicolumn{7}{|c|}{ Descriptive Statistics } \\
\hline & N & $\begin{array}{c}\text { Minim } \\
\text { um }\end{array}$ & $\begin{array}{c}\text { Maxim } \\
\text { um }\end{array}$ & Mean & $\begin{array}{c}\text { Std. } \\
\text { Deviati } \\
\text { on }\end{array}$ \\
\hline $\begin{array}{l}\text { CSR } \\
\text { Rating }\end{array}$ & 35 & 42,00 & 63,00 & 52,48 & 4,8469 \\
\hline $\begin{array}{l}\text { Return } \\
\text { On } \\
\text { Asset }\end{array}$ & 35 & 0,12 & 37,64 & 10,02 & 9,8099 \\
\hline $\begin{array}{l}\text { Net } \\
\text { Profit }\end{array}$ & 35 & 0,06 & 45,00 & 12,98 & 10,634 \\
\hline $\begin{array}{l}\text { Margi } \\
\text { n }\end{array}$ & & & & 89 & 62 \\
\hline $\begin{array}{l}\text { Tobin' } \\
\text { s Q }\end{array}$ & 35 & 0,83 & 16,26 & 2,355 & 2,6922 \\
\hline $\begin{array}{l}\text { Price } \\
\text { to } \\
\text { Book }\end{array}$ & 35 & 0,11 & 60,67 & 4,235 & 9,9866 \\
Value & & & & 2 & 3 \\
\hline $\begin{array}{l}\text { Valid } \\
\text { N } \\
\text { (listwi } \\
\text { se) }\end{array}$ & 35 & & & & \\
\hline
\end{tabular}

Sumber : data yang diolah dengan SPSS

Statistik deskriptif disajikan untuk memberikan gambaran mengenai sebaran data yang digunakan dalam penelitian ini. Nilai minimun dari CSR rating adalah 42, ROA 0,12, NPM 0,06, Tobin's Q 0,93 dan PBV 0,11. Nilai ini menunjukkan nilai rating, kinerja dan nilai perusahaan paling rendah dibandingkan dengan perusahaan di BEI tahun 2019 yang menjadi sampel dalam penelitian ini.

Nilai maximum dari CSR rating adalah 63, ROA 37,64, NPM 45,00, Tobin's Q 16,26 dan PBV 60,67. Nilai ini menunjukkan nilai CSR rating, kinerja dan nilai perusahaan paling tinggi dibandingkan dengan perusahaan di BEI tahun 2019 yang menjadi sampel dalam penelitian ini.

Nilai mean dari CSR rating adalah 52,4857, ROA 10,0231, NPM 12,9889, Tobin's Q 2.355 dan PBV 4,2352. Nilai ini menunjukkan nilai rata-rata CSR rating, kinerja dan nilai perusahaan dari perusahaan di BEI tahun 2019 yang menjadi sampel dalam penelitian ini

\section{Penilaian Outer Model}

Model yang digunakan dalam penelitian ini sedikit berubah karena variabel laten VALUE dalam pengujian outer model mengalami masalah multikolonearitas yakni VIF dari indikator TOBIN dan PBV mencapai 9,749 yang mana hal ini lebih dari 3. Sehingga peneliti memilih untuk mengeleminasi satu indikator yakni PBV untuk mengatasi masalah tersebut, kemudian melakukan pengujian ulang.

Dalam uji ini peneliti melakukan resampling untuk mengatasi keterbatasan jumlah sampel dengan metode bootstraping. Metode bootstraping dapat mengatasi masalah data tidak berdistribusi normal dalam pengujian.

Tabel 2 Significance of weights dan Multicolliniearity

\begin{tabular}{|c|c|c|c|}
\hline \multicolumn{2}{|c|}{ Variable } & $\begin{array}{c}\text { P } \\
\text { value }\end{array}$ & VIF \\
\hline RCSR & Rating CSR & $<0,001$ & 0.000 \\
\hline \multirow{2}{*}{ PROF } & ROA & 0,009 & 1.073 \\
\cline { 2 - 4 } & NPM & 0,01 & 1.073 \\
\hline VALUE & TOBIN & 0,048 & 0.000 \\
\hline RCSR*PROFIT & RCSR*PROFIT & 0,003 & 0.000 \\
\hline
\end{tabular}


Kock (2014, 2020) menjelaskan untuk menilai outer model secara formatif hanya membutuhkan penilaian terhadap indicator weight. Nilai dari signifikansi dan VIF (Variance Inflation factor) model harus memenuhi syarat yang mana signifikansi memiliki nilai $\mathrm{P}$ value $<0,05$ dan multikolonearitas sesuai rule of thumb tidak lebih dari 3. Signifikasi weight dari indikator Rating CSR $<0,001$, ROA 0,009, NPM 0,01, TOBIN 0,048 RCSR*PROFIT 0,003 dan VIF Rating CSR $<0,000$, ROA 1,073, NPM 1,073, TOBIN 0,000 RCSR*PROFIT 0,000 , maka dapat disimpulkan model dapat digunakan.

\section{Penilaian Inner Model}

Tabel 3 Nilai Adjusted $R$-squared dan Q-squared

\begin{tabular}{|l|l|l|}
\hline Variabel & $\begin{array}{l}\text { Adjusted R- } \\
\text { squared }\end{array}$ & $\begin{array}{l}\text { Q- } \\
\text { Square } \\
\text { d }\end{array}$ \\
\hline $\begin{array}{l}\text { Nilai Perusahaan } \\
\text { (VALUE) }\end{array}$ & 0,647 & 0,637 \\
\hline
\end{tabular}

Sumber: Data yang diolah oleh penulis 2021

Berdasarkan tabel 3 di atas nilai adjusted R-squared sebesar 0,647 yang artinya CSR Rating, kinerja perusahaan dan hubungan moderasi CSR rating dan kinerja perusahaan dapat menjelaskan $64,7 \%$ nilai perusahaan dan $35,3 \%$ dijelaskan dengan variabel lainnya di luar variabel penelitian ini. Nilai Q-squared sebesar 0,637 menunjukkan nilai prediktif yang baik karena lebih dari 0 .

Tabel 4 Model fit and quality indices Variabel Independen Terhadap Dependen

\begin{tabular}{|l|c|c|}
\hline Analisis General Result & & Ket. \\
\hline Average path coefficient (APC) & $\begin{array}{c}0.392, \\
\mathrm{P}=0.003\end{array}$ & Baik \\
\hline Average R-squared (ARS) & $\begin{array}{c}0.678, \\
\mathrm{P}=0.040\end{array}$ & Baik \\
\hline \begin{tabular}{l|c|} 
Average adjusted R-squared \\
(AARS)
\end{tabular} & $\begin{array}{c}0.647, \\
\mathrm{P}=0.078\end{array}$ & Baik \\
\hline Average block VIF (AVIF) & 1.096 & Ideal \\
\hline \multicolumn{2}{|c|}{ Sumber: Data yang diolah oleh penulis 2021 } \\
\hline
\end{tabular}

APC, ARS, dan AARS memiliki p-value 0.003, 0.040 dan 0.078 dan telah memenuhi kriteria karena nilai $\mathrm{P}<0.10$. AVIF dengan nilai 1.096 telah memenuhi kriteria karena $<=5$. Maka dapat ditarik kesimpulan model dalam pengujian ini layak diujikan.
Berikut peneliti sajikan gambar hubungan CSR rating, kinerja perusahaan terhadap nilai perusahaan dan moderasi CSR dalam hubungan kinerja perusahaan dengan nilai perusahaan.

Gambar 1 Output WarpPLS 7.0

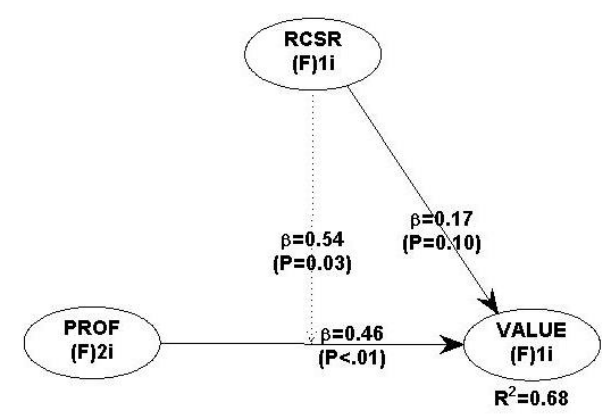

Sumber : Hasil Pengujian data dengan WarpPLS

Berdasarkan model pengujian dalam gambar 1 berikut hasil pengujian yang diperoleh :

Tabel 5 Hasil Uji Hipotesis

\begin{tabular}{|c|c|c|c|c|c|}
\hline $\begin{array}{l}\text { Hipo } \\
\text { tesis }\end{array}$ & $\begin{array}{c}\text { Ketera } \\
\text { ngan }\end{array}$ & $\begin{array}{l}\text { Path } \\
\text { Coeffi } \\
\text { cient }\end{array}$ & $\begin{array}{c}\mathbf{P} \\
\text { Val } \\
\text { ues }\end{array}$ & $\begin{array}{c}\text { Intrep } \\
\text { etasi } \\
\text { Arah } \\
\text { dan } \\
\text { Signifi } \\
\text { kansi }\end{array}$ & $\begin{array}{l}\text { Keput } \\
\text { usan }\end{array}$ \\
\hline H1 & $\begin{array}{l}\text { PROF } \\
> \\
\text { VALU } \\
\text { E }\end{array}$ & 0.463 & $\begin{array}{c}0.0 \\
08\end{array}$ & $\begin{array}{c}\text { Positif, } \\
\text { signifi } \\
\text { kansi } \\
\text { tinggi. }\end{array}$ & $\begin{array}{c}\text { Diteri } \\
\text { ma }\end{array}$ \\
\hline H2 & $\begin{array}{l}\text { RCSR } \\
> \\
\text { VALU } \\
\text { E }\end{array}$ & 0.173 & $\begin{array}{l}0.1 \\
05\end{array}$ & $\begin{array}{c}\text { Positif, } \\
\text { signifi } \\
\text { kansi } \\
\text { lemah }\end{array}$ & $\begin{array}{c}\text { Diteri } \\
\text { ma }\end{array}$ \\
\hline H3 & $\begin{array}{l}\text { RCSR* } \\
\text { PROF } \\
> \\
\text { VALU } \\
\text { E }\end{array}$ & 0.542 & $\begin{array}{l}0.0 \\
27\end{array}$ & $\begin{array}{c}\text { Positif, } \\
\text { signifi } \\
\text { kan. }\end{array}$ & $\begin{array}{c}\text { Diteri } \\
\text { ma }\end{array}$ \\
\hline
\end{tabular}

Sumber : Hasil pengujian data dengan WarpPLS

Berdasarkan tabel di atas, $\mathrm{H} 1$ diterima dengan nilai koefisien 0.463 dengan P Value 0.008 di bawah 0,01 yang artinya berpengaruh positif dengan signifikansi tinggi. Selanjutnya H2 diterima dengan nilai koefisien positif 0.173 dengan $\mathrm{P}$ Value < 0.105 signifikan di 0.10 yang artinya berpengaruh positif dengan signifikansi lemah. Selanjutnya H3 
diterima dengan nilai koefisien positif 0.542 dengan P Value 0.027 yaitu di bawah 0.05 yang artinya dapat memoderasi secara positif.

Hasil pada tabel di atas dapat dijelaskan dengan persamaan sebagai berikut :

$$
\begin{gathered}
\text { VALUE }=0.463 \text { PROF }+0.173 \text { RCSR }+0.542 \\
\text { RCSR } * \text { PROF }
\end{gathered}
$$

\section{PEMBAHASAN}

Berdasarkan hasil uji penelitian dalam tabel 5 menemukan hasil bahwa kinerja perusahaan punya hubungan yang sangat erat dengan nilai perusahaan sehingga $\mathrm{H} 1$ dapat dinyatakan diterima. Hasil ini konsisten dengan penelitian-penelitian sebelumnya milik Harningsih et al., (2019); Haryanto et al., (2018); dan Nursani, (2020). Hasil positif menunjukkan semakin besar kemampuan perusahaan menciptakan laba dalam satu periode tertentu maka akan meningkatkan nilai perusahaan. Hal ini karena calon investor akan melihat perusahaan sebagai entitas yang menjamin pengembalian dari investasinya sehingga banyak yang akan menginvestasikan dananya perusahaan tersebut. Lalu hal ini juga memberi gambaran baiknya perusahaan dalam mengelola asetnya berdasarkan keputusan-keputusan manajerial yang baik akan meningkatkan nilai perusahaan.

Hasil uji CSR rating menunjukkan signifikansi yang lemah dengan arah dari koefisien adalah positif. Hal ini dapat memberikan gambaran jika pada dasarnya rating yang diberikan agensi belum mendapatkan awareness investor dan perusahaan di Indonesia. Namun keberadaan CSR rating tetap dapat meningkatkan nilai perusahaan karena menunjukkan tanggung jawab perusahaan yang telah dilakukan dengan memerhatikan aspek lingkungan, sosial dan tata kelola perusahaan. Sahut \& Pasquini-Descomps (2015) menjelaskan lemahnya hubungan CSR rating dengan nilai perusahaan karena banyak investor belum sadar bahwa dengan CSR rating dapat menunjukkan tinggi rendahnya resiko untuk menginvestasikan modalnya pada perusahaan. Hasil ini sejalan dengan Wong et al. (2020) dan Yoon et al. (2018) yang menemukan bahwa rating CSR dapat meningkatkan nilai perusahaan.

Hasil uji moderasi dari CSR rating dalam hubungan kinerja perusahaan dengan nilai perusahaan dilakukan dengan melihat signifikansi jika kurang dari 0,05 maka dapat ditarik kesimpulan dapat memoderasi (Baron \& Kenny, 1986). Dalam pengujian menunjukkan bahwa hasil positif signifikan. Hasil ini menunjukkan bahwa CSR rating dapat memperkuat hubungan dari kinerja perusahaan dengan nilai perusahaan. artinya nilai yang didapat dari agensi rating CSR akan meningkatkan nilai perusahaan. Ini memungkinkan bagi banyak stakeholder melihat kemungkinan baru dalam mengelola perusahaan dengan memerhatikan tanggung jawab. Ketika perusahaan melaksanakan nilai-nilai etis dalam menjalankan perusahaan hal ini akan menjadi sinyal bagi investor bahwa perusahaan yang akan diinvestasikan dana tidak hanya baik dalam menghasilkan laba namun juga kepastian akan keberlanjutan perusahaan

\section{KESIMPULAN}

Penelitian ini bertujuan untuk mengetahui hubungan dari kinerja perusahaan, CSR rating dan nilai perusahaan pada perusahaan yang terdaftar di BEI di tahun 2019. Variabel yang digunakan dalam penelitian ini meliputi CSR Rating, Return On Asset, Net Profit Margin, Tobin's Q, Price to Book Value yang diwujudkan secara formatif dalam pengujian PLS dengan software WarpPLS.

Dari penelitian ini bisa kita tarik kesimpulah bahwa :

1. CSR rating memiliki pengaruh positif terhadap nilai perusahaan.

2. Kinerja keuangan perusahaan pengaruh positif terhadap nilai perusahaan.

3. CSR rating dapat memoderasi hubungan kinerja keuangan perusahaan dengan nilai perusahaan.

Dari penelitian ini mengungkapkan bahwa dalam pengujian kinerja perusahaan, CSR rating dan moderasi kinerja perusahaan dengan CSR rating terhadap nilai perusahaan menjelaskan nilai perusahaan sebesar 68\%. Dapat dilihat di sini bahwa investor di Indonesia selain mengedepankan keuntungan perusahaan, investor Indonesia juga melihat faktor tanggung jawab perusahaan. Hal tersebut lah yang mendorong meningkatnya nilai perusahaan. ini dibuktikan dalam penelitian ini semua variabel menunjukkan arah yang positif.

\section{Daftar Pustaka}

Ali, H. Y., Danish, R. Q., \& Asrar-ul-Haq, M. (2020). How corporate social responsibility boosts firm financial performance: The 
mediating role of corporate image and customer satisfaction. Corporate Social Responsibility and Environmental Management, 27(1), 166-177. https://doi.org/10.1002/csr.1781

Ali, M. R., Mahmud, M. S., \& Lima, R. P. (2016). Analyzing Tobin's Q Ratio of Banking Industry of Bangladesh: A Comprehensive Guideline for Investors. Asian Business Review, 6(2), 85. https://doi.org/10.18034/abr.v6i2.851

Atan, R., Alam, M. M., Said, J., \& Zamri, M. (2018). The impacts of environmental, social, and governance factors on firm performance: Panel study of Malaysian companies. Management of Environmental Quality: An International Journal, 29(2), 182-194. https://doi.org/10.1108/MEQ-03-2017-0033

Baron, R. M., \& Kenny, D. A. (1986). The Moderator-Mediator Variable Distinction in Social Psychological Research: Conceptual, Strategic, and Statistical Considerations. Journal of Personality and Social Psychology, 51(6), 1173-1182. https://doi.org/10.1007/BF02512353

Brigham, E. F., \& Houston, J. F. (2015). Fundamental of Financial Management (14 ed.). Boston: Cengage Learning.

Crisóstomo, V. L., De Souza Freire, F., \& De Vasconcellos, F. C. (2011). Corporate social responsibility, firm value and financial performance in Brazil. Social Responsibility Journal, 7(2), 295-309. https://doi.org/10.1108/17471111111141549

Effendi, R. (2019). MEMBANGUN NILAI PERUSAHAAN BERBASIS PEMANGKU KEPENTINGAN (Build Value Based of Corporate Stakeholder's). Goodwill : Jurnal Penelitian Akuntansi, 1(2), 89-94.

Harningsih, S., Agustin, H., \& Setiawan, M. A. (2019). Pengaruh Kinerja Keuangan Terhadap Nilai Perusahaan Dengan Pengungkapan CSR Dan Kebijakan Dividen Sebagai Variabel Moderasi. Ranah Research Journal of Multidisciplinary Research and Development, 1(2), 199-209.

Haryanto, S., Rahadian, N., Mbapa, M. F. I., Rahayu, E. N., \& Febriyanti, K. V. (2018). Kebijakan Hutang, Ukuran Perusahaan dan Kinerja Keuangan Terhadap Nilai Perusahaan: Industri Perbankan di Indonesia. AFRE (Accounting and Financial Review), 1(2), 62-70.

https://doi.org/10.26905/afr.v1i2.2279
Helfert, E. a. (2001). Financial Analysis Tools and Techniques: A Guide for Managers. In New York, McGraw-Hill.

Karina, D. R. M., \& Setiadi, I. (2020). Pengaruh CSR Terhadap Nilai Perusahaan Dengan GCG Sebagai Pemoderasi. Jurnal Riset Akuntansi Mercu Buana, 6(1), 37. https://doi.org/10.26486/jramb.v6i1.1054

Kock, N. (2014). Advanced Mediating Effects Tests, Multi-Group Analyses, and Measurement Model Assessments in PLSBased SEM. International Journal of eCollaboration, 10(1), 1-13. https://doi.org/10.4018/ijec.2014010101

Kock, N. (2020). WarpPLS User Manual 7.0. Diambil dari www.scriptwarp.com

Lindawati, A. S. L., \& Puspita, M. E. (2015). Corporate Social Responsibility: Implikasi Stakeholder dan Legitimacy Gap dalam Peningkatan Kinerja Perusahaan. Jurnal Akuntansi Multiparadigma, 6(1), 157-174. https://doi.org/10.18202/jamal.2015.04.6013

Lindgreen, A., \& Swaen, V. (2010). Corporate social responsibility. International Journal of Management Reviews, 12(1), 1-7. https://doi.org/10.1111/j.14682370.2009.00277.x

Masruroh, A., \& Makaryanawati, M. (2020). Pengaruh Pengungkapan Tanggung Jawab Sosial terhadap Nilai Perusahaan pada Perusahaan Pertambangan yang Terdaftar di Bursa Efek Indonesia. Jurnal Akuntansi Aktual, 7(1), 67-80. https://doi.org/10.17977/um004v7i12020p67

Maulana, I. (2020). ANALISIS PENGARUH DEWAN KOMISARIS INDEPENDEN, KEPEMILIKAN MANAJERIAL DAN KEPEMILIKAN INSTITUSIONAL TERHADAP KINERJA PERUSAHAAN JASA KEUANGAN DI INDONESIA. Jurnal REKSA Rekayasa Keuangan, Syariah, dan Audit, 7(01), 11-23.

Mudjijah, S., Khalid, Z., \& Astuti, D. A. S. (2019). Pengaruh Kinerja Keuangan dan Struktur Modal Terhadap Nilai Perusahaan yang Dimoderasi Variabel Ukuran Perusahaan. Jurnal Akuntansi dan Keuangan, 8(1), 41-56.

Nursani, E. (2020). PENGARUH KINERJA KEUANGAN TERHADAP NILAI PERUSAHAAN DENGAN CSR SEBAGAI VARIABEL MODERASI. AKTIVA Jurnal Akuntansi dan Investasi, 5(1), 29-44. Diambil dari http://publication.petra.ac.id/index.php/manaj 
emen-keuangan/article/view/2961

Padmayanti, N. P. E. W., Suryadani, N. N. A., \& Munidewi, I. . B. (2019). PENGARUH

KINERJA KEUANGAN TERHADAP NILAI PERUSAHAAN DENGAN DEWAN KOMISARIS INDEPENDEN SEBAGAI VARIABEL PEMODERASI PADA PERUSAHAAN MANUFAKTUR YANG TERDAFTAR DI BURSA EFEK INDONESIA. Juara : Jurnal Riset Akuntansi, 9(1), 62-72. https://doi.org/10.1145/3132847.3132886

Rafid, A. G., Pohan, H. T., \& Noor, I. N. (2017). PENGARUH KINERJA KEUNGAN TERHADAP NILAI PERUSAHAAN DENGAN PENGUNGKAPAN CORPORATE SOCIAL RESPONSIBILITY SEBAGAI VARIABEL PEMODERASI. Jurnal Akuntansi Trisakti, 4(2), 245-258. https://doi.org/http://dx.doi.org/10.25105/jat. v4i2.4838

Rashid, M. M. (2020). Ownership structure and firm performance: the mediating role of board characteristics. Corporate Governance (Bingley), 20(4), 719-737. https://doi.org/10.1108/CG-02-2019-0056

Saadaoui, K., \& Soobaroyen, T. (2018). An analysis of the methodologies adopted by CSR rating agencies. Sustainability Accounting, Management and Policy Journal, 9(1), 43-62. https://doi.org/10.1108/SAMPJ-06-20160031

Sahut, J.-M., \& Pasquini-Descomps, H. (2015). ESG Impact on Market Performance of Firms: International EvidenceL'impact des facteurs ESG sur la performance en bourse des entreprises : incidences internationalesEl impacto de ESG en la rentabilidad de mercado de las empresas. Management international, 19(2), 40.

Sandberg, J., Juravle, C., Hedesström, T. M., \& Hamilton, I. (2009). The heterogeneity of socially responsible investment. Journal of Business Ethics, 87(4), 519-533. https://doi.org/10.1007/s10551-008-9956-0

Scalet, S., \& Kelly, T. F. (2010). CSR rating agencies: What is their global impact? Journal of Business Ethics, 94(1), 69-88. https://doi.org/10.1007/s10551-009-0250-6

Seok, J., Lee, Y., \& Kim, B. Do. (2020). Impact of CSR news reports on firm value. Asia Pacific Journal of Marketing and Logistics, 32(3), 644-663. https://doi.org/10.1108/APJML-062019-0352
Solimun, Fernandes, A. A. R., \& Nurjannah. (2017). Metode Statistika Multivariat Pemodelan Persamaan Struktural (SEM) Pendekatan WarpPLS. Malang: UB Press.

Sugiyono, P. D. (2017). Metode Penelitian Bisnis: Pendekatan Kuantitatif, Kualitatif, Kombinasi, dan R\&D. Bandung: CV. Alfabeta.

Titman, S., Keown, A. J., \& Martin, J. D. (2017). Financial management : principles and applications (13 ed.). Harlow: Pearson Education Limited.

Tsai, C. H., \& Mutuc, E. B. (2020). Evidence in Asian food industry: Intellectual capital, corporate financial performance, and corporate social responsibility. International Journal of Environmental Research and Public Health, 17(2). https://doi.org/10.3390/ijerph17020663

Wong, W. C., Batten, J. A., Ahmad, A. H., Mohamed-Arshad, S. B., Nordin, S., \& Adzis, A. A. (2020). Does ESG certification add firm value? Finance Research Letters, 101593. https://doi.org/10.1016/j.frl.2020.101593

Yoon, B., Lee, J. H., \& Byun, R. (2018). Does ESG performance enhance firm value? Evidence from Korea. Sustainability (Switzerland), 10(10). https://doi.org/10.3390/su10103635 
